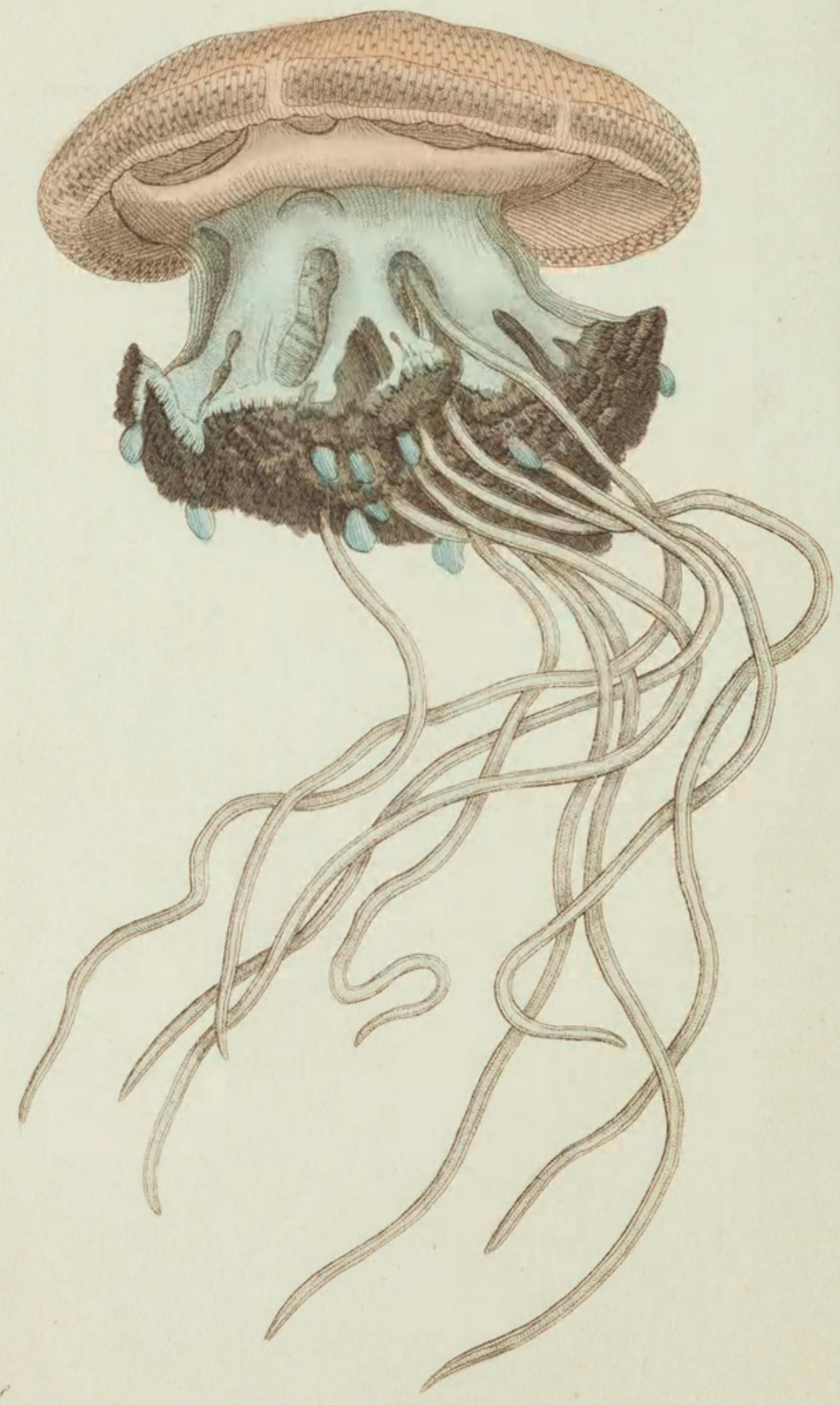




\section{MEDUSA CEPHEA.}

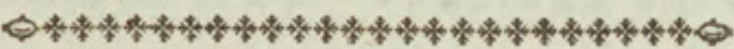

CHARACTER GENERICUS.

Corpus gelatinofum, orbiculatum, depreffum. Os fubtus, centrale.

$$
\text { Lin. Syft. Nat. p. } 1096 .
$$

CHARACTER SPECIFICUS, $\mathcal{\Xi}^{2}$.

MEDUSA hemifphærico-depreffa fufco-rufefcens, fubtus brachiis octo apice villofis, tentaculifque novem filiformibus longiffimis.

MEDUSA hemifphærica tuberculata fufco-rufefcens, margine crenato, brachiis fubtus octo lanatis.

$$
\begin{aligned}
& \text { Lin. Syft. Nat. Gmel. p. } 315^{8 .} \\
& \text { Forjk. Fn. Aegypt. Arab. p. } 108 \text {. n. } 22 .
\end{aligned}
$$

Medufa Cephea, quæ inter majores numeratur, pellucida admodum eft, et gelata, palletque fufcorufefcens, in nonnullis partibus obfcurior et fere fubcærulea. Circa litora maris rubri, non infrequens reperitur. 


\section{CEPHEAN MEDUSA.}

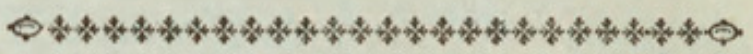

\section{GENERIC CHARACTER.}

Body gelatinous, orbicular, commonly depreffed. Mouth central, beneath.

$$
\text { SPECIFIC CHARACTER, EC. }
$$

HEMISPHERIC-DEPRESSED REDDISHBROWN MEDUSA; furnifhed with eight arms, villous at their extremities, and with nine very long filiform tentacula.

This is one of the larger Medufa: it is extremely pellucid, of a gelatinous confiftence, and of a pale reddifh-brown color, tinged in fome parts with a darker hue, approaching nearly to blueifh. It is not uncommon towards the coafts of the Red Sea. 


\section{$2 \mathrm{BHL}$ Biodiversity Heritage Library}

Shaw, George. 1795. "The Cephean Medusa, Medusa cephea [PI. 224]." The Naturalist's Miscellany 7(LXXIV), https://doi.org/10.5962/p.310767.

View This Item Online: https://www.biodiversitylibrary.org/item/276356

DOI: https://doi.org/10.5962/p.310767

Permalink: https://www.biodiversitylibrary.org/partpdf/310767

\section{Holding Institution}

Museums Victoria

\section{Sponsored by}

Atlas of Living Australia

\section{Copyright \& Reuse}

Copyright Status: Public domain. The BHL considers that this work is no longer under copyright protection.

This document was created from content at the Biodiversity Heritage Library, the world's largest open access digital library for biodiversity literature and archives. Visit BHL at https://www.biodiversitylibrary.org. 